\title{
Vitamin D and Diabetic Complications: True or False Prophet?
}

Uazman Alam • Vilashini Arul-Devah · Saad Javed •

Rayaz A. Malik

Received: May 18, 2015 / Published online: March 12, 2016

(C) The Author(s) 2016. This article is published with open access at Springerlink.com

\section{ABSTRACT}

Vitamin D deficiency is now recognized as a condition of increasing prevalence worldwide. Vitamin D has an established role in calcium and bone metabolism; however, more recently associations with vitamin D deficiency and risk of developing diabetes, diabetes complications, and cardiovascular disease have all been acknowledged. The vitamin $\mathrm{D}$ receptor is ubiquitously expressed, and experimental, in vitro, and in vivo studies strongly suggest a role in regulating the transcription of multiple genes beyond calcium homeostasis. These include antiproliferative, immunomodulatory, angiogenic, inhibition of the

Enhanced content To view enhanced content for this article go to http://www.medengine.com/Redeem/ 2844F0604CA6B39D.

U. Alam $(\bowtie) \cdot$ V. Arul-Devah · S. Javed · R. A. Malik Centre for Endocrinology and Diabetes, Institute of Human Development, University of Manchester and the Manchester Royal Infirmary, Central Manchester Hospital Foundation Trust, Manchester, UK

e-mail: uazman.alam@manchester.ac.uk

R. A. Malik

Weill Cornell Medicine-Qatar, Qatar Foundation, Doha, Qatar renin-angiotensin-aldosterone system, and neurotrophic factor expression. Observational studies report a strong association between vitamin $\mathrm{D}$ deficiency and cardiovascular and metabolic disorders; however, there remains a paucity of large long-term randomized clinical trials showing a benefit with treatment. An increasing body of literature suggests a possible pathogenetic role of vitamin $\mathrm{D}$ in the long-term complications of diabetes and vitamin D deficiency may also exacerbate symptoms of painful diabetic peripheral neuropathy. It remains unknown if supplementation of vitamin $\mathrm{D}$ to normal or non-deficient levels alters pathogenetic processes related to diabetic microvascular complications. With the high prevalence of vitamin $\mathrm{D}$ deficiency in patients with diabetes and putative mechanisms linking vitamin $\mathrm{D}$ deficiency to diabetic complications, there is a compelling argument for undertaking large well-designed randomized controlled trials of vitamin D supplementation.

Keywords: Cardiovascular disease; Diabetic nephropathy; Diabetic neuropathy; Diabetic retinopathy; Pain; RAAS inhibition; Vitamin D 


\section{INTRODUCTION}

There is an epidemic of vitamin D deficiency, with over one billion people worldwide affected [1]. Our previously published UK data indicates that vitamin $\mathrm{D}$ deficiency (25-hydroxyvitamin D [25(OH)D] $<30 \mathrm{ng} / \mathrm{mL}$ ) occurs in $91 \%$ of patients with diabetes, with severe deficiency $[25(\mathrm{OH}) \mathrm{D}<10 \mathrm{ng} / \mathrm{mL}]$ in $32 \%$ of patients [2]. The purpose of this review was to examine the association between vitamin D status and cardiovascular disease, with particular reference to diabetes mellitus and its complications.

This review is based on previously conducted studies and does not involve any new studies of human or animal subjects performed by any of the authors.

\section{VITAMIN D AND THE VITAMIN D RECEPTOR}

Vitamin D is a lipid-soluble, secosteroid hormone which is primarily associated with calcium homeostasis [3]. Synthesis of vitamin D occurs predominantly in the skin from dehydrocholesterol, the shared common precursor with cholesterol, and is dependent on sun exposure [4]. Ultraviolet B light of wavelengths between 280 and $315 \mathrm{~nm}$ is optimal for the conversion of 7-dehydrocholesterol to previtamin $\mathrm{D}_{3}$, which is then converted to vitamin $\mathrm{D}_{3}$ in the skin. During summer, exposure to midday sunlight for $20-30 \mathrm{~min}$, two or three times per week is thought to be sufficient in generating adequate levels of vitamin $\mathrm{D}$ for a fair-skinned individual [5]. Table 1 outlines the significant risk factors for vitamin D deficiency. The amount of synthesized vitamin $\mathrm{D}$ is reduced in darker-skinned, older, and obese individuals
Table 1 Significant risk factors for vitamin D deficiency

Increasing age

Use of sunscreen

Pigmented skin

House-bound patients

Obesity

Northern latitudes

Medication (antiepileptic/antiretroviral drugs)

Renal disease

Liver disease

Malabsorption syndrome

[5]. Other sources of vitamin D include diet (food that contains natural vitamin D or fortified vitamin D) and dietary supplements [3]. Dietary vitamin D usually contains vitamin $\mathrm{D}_{3}$ (cholecalciferol) with few natural sources containing vitamin $\mathrm{D}_{2}$ (ergocalciferol) [3]. Vitamin D from the skin and diet is modified in the liver to generate $25(\mathrm{OH}) \mathrm{D}$ [3]. Active vitamin $\mathrm{D}$ is formed when further conversion takes place in the kidneys forming 1,25-dihydroxyvitamin D $\quad\left[1,25(\mathrm{OH})_{2} \mathrm{D}_{3}\right.$ (activated vitamin D)] [3].

Vitamin D status is defined by measuring the level of $25(\mathrm{OH}) \mathrm{D}$ in the blood owing to its longer half-life in plasma, where it forms a circulating reservoir of vitamin D [3]. A serum concentration of $>30 \mathrm{ng} / \mathrm{mL}(>75 \mathrm{nmol} / \mathrm{L})$ is considered as sufficient, $20-30 \mathrm{ng} / \mathrm{mL}$ (50-75 nmol/L) as insufficient, $10-20 \mathrm{ng} / \mathrm{mL}$ $(25-50 \mathrm{nmol} / \mathrm{L})$ as deficient, and $<10 \mathrm{ng} / \mathrm{mL}$ $(<25 \mathrm{nmol} / \mathrm{l})$ as severely deficient [3]. The US Institute of Medicine (IoM) released guidance in 2011 in which 25(OH)D equal to $20 \mathrm{ng} / \mathrm{mL}$ was considered to be adequate for $\geq 97.5 \%$ of the population [6]; however, this has been heavily criticized by the Endocrine Society $[7,8]$ and 
Table 2 Serum 25-hydroxyvitamin D concentrations and status

\begin{tabular}{ll}
\hline $\begin{array}{l}\mathbf{2 5}(\mathbf{O H}) \text { vitamin }_{\text {D }} \\
\text { concentration }^{\mathbf{a}}\end{array}$ & $\begin{array}{l}\mathbf{2 5}(\mathbf{O H}) \text { vitamin } \mathbf{D} \\
\text { status }\end{array}$ \\
\hline$<10 \mathrm{ng} / \mathrm{mL}$ & Severe deficiency \\
$10-<20 \mathrm{ng} / \mathrm{mL}$ & Deficient \\
$20-<30 \mathrm{ng} / \mathrm{mL}$ & Insufficient \\
$\geq 30 \mathrm{ng} / \mathrm{mL}$ & Adequate \\
$\geq 100 \mathrm{ng} / \mathrm{mL}$ & Possible toxicity \\
\hline
\end{tabular}

${ }^{a}$ Multiply by 2.5 to convert to $\mathrm{nmol} / \mathrm{L}$

they recommend that $25(\mathrm{OH}) \mathrm{D}$ concentration should exceed $30 \mathrm{ng} / \mathrm{mL}$, to maximize the effect of vitamin $\mathrm{D}$ on calcium, bone, and muscle metabolism. Cutoffs for vitamin D status are detailed in Table 2. Both the IoM and the Endocrine Society have arbitrated respective cutoffs for optimal vitamin D status; however, these are based on bone metabolic data and not on cardiometabolic data [9]. Optimal levels of $25(\mathrm{OH}) \mathrm{D}$ for possible prevention of cardiometabolic outcomes remain to be elucidated [10].

Vitamin D insufficiency which is not low enough to cause bone disease is significantly associated with cardiovascular disease [11]. There is a ubiquitous expression of vitamin D receptors (VDR) in virtually every human tissue, and vitamin $\mathrm{D}$ is an important regulator of literally hundreds of genes regulating key biological processes from cell division to apoptosis [11].

VDR is widely distributed in many tissues [12], which suggests a putative biological response with its activation, implying that VDR has multiple functions beyond calcium homeostasis [12]. Once $1,25(\mathrm{OH})_{2} \mathrm{D}_{3}$ binds to $\mathrm{VDR}$, it interacts with the retinoid $\mathrm{X}$ receptor (RXR) forming a heterodimer that binds to vitamin $\mathrm{D}$ responsive elements in the region of genes directly controlled by $1,25(\mathrm{OH})_{2} \mathrm{D}_{3}$ [13]. The action of vitamin $\mathrm{D}$ in a particular cell depends on the vitamin D-mediated gene activation, transcriptional response, and protein formation [13]. For example, in addition to stimulating intestinal calcium and phosphate absorption to effect skeletal and mineral ion homeostasis, $1,25(\mathrm{OH})_{2} \mathrm{D}_{3} /$ VDR-RXR also regulates the expression of a plethora of genes in non-calcemic tissues [12]. This extensive vitamin "D-ome" allows the concerted genomic and rapid actions of $1,25(\mathrm{OH})_{2} \mathrm{D}_{3}$ to possibly have an interplay with such varied diseases as osteoporosis, cancer, diabetes, atherosclerosis, vascular disease/calcification, and infection [12]. Furthermore, the VDR gene is expressed within developing neurons of rodent dorsal root ganglia, which may suggest a role for vitamin $\mathrm{D}$ in peripheral nervous system development and nociception [14].

\section{VITAMIN D AND CARDIOVASCULAR DISEASE}

The Framingham Offspring Study assessed subjects with no prior diagnosis of cardiovascular disease. Subjects with severe vitamin D deficiency $(25(\mathrm{OH}) \mathrm{D}<10 \mathrm{ng} / \mathrm{mL})$ experienced a hazard ratio of 1.80 [95\% confidence interval (CI), 1.05-3.08] for developing a first cardiovascular event 5 years after follow-up compared with subjects with higher levels of $25(\mathrm{OH}) \mathrm{D}(>15 \mathrm{ng} / \mathrm{mL})$ [15]. In the Health Professionals Follow-Up Study, men without prior cardiovascular disease and vitamin D levels of $<15 \mathrm{ng} / \mathrm{mL}$ showed a twofold increase in the rate of myocardial infarction [16]. A cross-sectional study by Dobnig et al. [17] found an inverse relationship between lower levels of vitamin D 
and increased risk of all-cause and cardiovascular mortality. Other cross-sectional observational studies have confirmed that lower vitamin D levels are associated with endothelial dysfunction as well as arterial stiffness [18]. The vasoprotective action of vitamin $\mathrm{D}$ may be mediated by increasing nitric oxide (NO) production, inhibiting foam cell formation, and reducing the expression of adhesion molecules in endothelial cells [19-21]. The recognition of specific VDR genetic susceptibility in the pathophysiology of hypertension has further supported these insights [22]. With regards to cerebrovascular disease, in a large population-based prospective study in Copenhagen, an increase risk of symptomatic ischemic stroke was observed with decreasing plasma 25(OH)D concentrations [23]. A similar association with vitamin D deficiency was also demonstrated in the Honolulu Heart Program, which studied 7385 men over a 34-year period [24]. In a study of 250 stroke patients in India, a deficiency of $25(\mathrm{OH}) \mathrm{D}$ was independently associated with ischemic stroke, especially large artery atherosclerosis and cardioembolic stroke [25]. Studies are needed to establish if vitamin D supplementation reduces the risk of ischemic stroke in the general population.

Li et al. established that VDR knockout mice have elevated blood pressure, cardiac hypertrophy, and elevated activation of the renin-angiotensin-aldosterone system (RAAS), which can be reversed with an angiotensin-converting enzyme (ACE) inhibitor $[26,27]$. RAAS plays a pivotal role in maintaining sodium and blood volume homeostasis by modulating renal function and blood pressure [28]. Upregulation of RAAS leads to the development of hypertension and increased cardiovascular risk [28]. RAAS induces recruitment and activation of inflammatory cells within the vessel wall, promoting endothelial dysfunction and increasing vascular permeability [28]. This inflammatory response stimulates hyperplasia and hypertrophy of vascular smooth muscle cells and the release of pro-inflammatory molecules (VCAM-1, monocyte chemoattractant protein-1, interleukins 6 and 8) [28]. Li et al. also showed that wild-type mice given an injection of $1,25(\mathrm{OH})_{2} \mathrm{D}_{3}$ demonstrated suppression of renin mRNA expression [26, 27]. Vitamin D is a potent negative regulator of the RAAS system, which may play an important role in the development of neuropathy in diabetes. RAAS inhibition is one of the few proven therapies, which may prevent or delay diabetic peripheral neuropathy (DPN), evidenced by experimental studies but also two human clinical trials [29-31]. In an experimental model of type 1 diabetes mellitus, plasma renin activity levels were decreased whereas ACE activity was increased in diabetic rats compared with controls [31]. A small open-label study of lisinopril in hypertensive subjects $(n=13)$ showed improvements in nerve conduction measures over 12 weeks [29] and a double-blind randomized controlled study found that administration of the ACE inhibitor trandolapril in normotensive patients with mild diabetic neuropathy resulted in an improvement in neurophysiology over 12 months [30].

In a randomized controlled trial (RCT) by Trivedi et al. [32], vitamin $\mathrm{D}_{3} 100,000 \mathrm{IU}$ was supplemented every 4 months for 5 years versus placebo to assess fracture risk. There was a non-significant trend [risk ratio (RR), 0.84; 95\% CI, 0.055-1.10] toward a reduction in cardiovascular deaths. A further RCT $(n=302)$ added vitamin $\mathrm{D}$ to ongoing calcium supplementation with a primary endpoint of the risk of falls [33]. They reported as adverse 
events ischemic heart disease event rates of $1.3 \%$ in those on vitamin D versus $2.0 \%$ for placebo (only two versus three events). These two RCTs were analyzed in a meta-analysis which reported no significant benefit for vitamin D supplementation [34]. In the Women's Health Initiative (WHI) study (ClincialTrials.gov identifier, NCT00000611), 36,282 women were randomized to receive a combination of vitamin $\mathrm{D}_{3} 400 \mathrm{IU}$ and calcium $1000 \mathrm{mg}$ per day or placebo [35]. Myocardial infarction or coronary heart disease death was confirmed for 499 women assigned to calcium/ vitamin $\mathrm{D}$ and 475 women assigned to placebo (hazard ratio, 1.04; 95\% CI, 0.92-1.18) [35]. It was concluded that calcium plus vitamin D supplementation neither increased nor decreased coronary or cerebrovascular risk in generally healthy postmenopausal women over a 7-year use period [36].

\section{VITAMIN D AND DIABETES}

VDR have also been identified in pancreatic beta cells, and vitamin D deficiency has been shown to impair insulin synthesis and secretion in animal models of diabetes, suggesting a role in the development of type 2 diabetes [37]. Vitamin D deficiency is known to increase the levels of parathyroid hormone. This in turn has been linked to increased insulin resistance, which is associated with diabetes, hypertension, inflammation, and increased cardiovascular risk [38]. Several studies, including one published by Scragg et al. [39], demonstrated that lower vitamin $\mathrm{D}$ levels were associated with an increased risk of diabetes [28]. A double-blinded placebo trial by Mitri et al. [40] showed that in adults at risk of type 2 diabetes, short-term supplementation with cholecalciferol improved beta cell function and had a marginal effect on attenuating the rise in HbA1c. Furthermore, two studies have shown an inverse relationship of $25(\mathrm{OH}) \mathrm{D}$ with HbA1c in subjects with and without diabetes $[41,42]$. Devaraj et al. [43] found that the first quartile of serum 25(OH)D level, compared with the fourth quartile, was associated with an increased adjusted odds ratio (OR) for prediabetes and vitamin $\mathrm{D}$ levels were inversely correlated with fasting glucose $(r=-0.29, P=0.04)$ and homeostasis model assessment (HOMA) $(r=-0.34, \quad P=0.04)$. However, in the WHI study, of 33,951 participants receiving calcium plus vitamin $D_{3}$ supplementation, there was no reduction in the risk of developing diabetes over 7 years [36]. Vitamin D also has an immunomodulatory effect as suggested by a study of more than 10,000 Finnish children who were given 2000 IU vitamin $D_{3}$ per day during the first year of life and demonstrated an astounding $78 \%$ reduced risk of type 1 diabetes over a 30-year follow-up [44]. A small placebo controlled trial of vitamin $\mathrm{D}_{3}$ (4000 IU/day for 6 months) supplementation showed reduced insulin resistance in a South Asian population who were vitamin D deficient [45].

Recently, in an observational study of patients in the 5-year Fenofibrate Intervention and Event Lowering in Diabetes (FIELD) trial, low blood 25(OH)D concentrations were associated with an increased risk of macrovascular and microvascular disease events in type 2 diabetes [46]. A 25(OH)D concentration $<20 \mathrm{ng} / \mathrm{mL}$ had a higher cumulative incidence of macrovascular and microvascular events than those with levels $\geq 20 \mathrm{ng} / \mathrm{mL}$ [46]. Indeed severe vitamin D deficiency has been shown to predict not only mortality but the development of nephropathy and retinopathy in type 1 diabetes [47]. 


\section{VITAMIN D, NERVES, AND DIABETIC NEUROPATHY}

Previously studies of vitamin D have largely focused on bone health and calcium metabolism [1]; however, an increasing body of evidence particularly over the past two decades implicates a role of vitamin $\mathrm{D}$ in the nervous system [48, 49]. Multiple neurodegenerative diseases including multiple sclerosis [50-54] and Parkinson's disease [55], as well as cognitive decline in the elderly [56], have been linked with declining vitamin D status. There are some data to suggest that treatment with high doses of vitamin $\mathrm{D}_{3}$ slows down the progression of disability linked to multiple sclerosis [57]; however, further larger interventional studies are required to truly assess any therapeutic benefit [58].

Nerve growth factor (NGF) was first identified as being essential for the development of nociceptive primary neurons and later found to have a role in inflammatory hyperalgesia in adults [59]. NGF is a neurotrophic factor which is synthesized initially as pro-NGF, prior to being cleaved by intracellular proteases before being translocated to the rough endoplasmic reticulum and is cleaved a second time by extracellular proteases to produce the active form [59]. NGF is responsible for the development and maintenance of neurons in several regions in the central nervous system $[59,60]$. In addition, following neuronal injury, NGF has the ability to promote myelination of Schwann cells, stimulate axonal sprouting, and guide axonal growth [61]. 1,25(OH) ${ }_{2} \mathrm{D}_{3}$ has been shown to cross the blood-brain barrier in experimental models [62] and may act with relative specificity to increase NGF in glial cells [63] and fibroblasts [64]. Its receptors are found in the brain in discrete regions [65]. In experimental studies, vitamin $\mathrm{D}$ has been linked to the regulation of neurotrophins such as NGF and neuronal $\mathrm{Ca}^{2+}$ homeostasis, both of which may play a neuroprotective role in the peripheral nerve [66]. Riaz et al. [66] showed that sciatic nerve NGF was preserved in animals exposed to a vitamin D analogue (CB1093) whilst another vitamin D analogue (MC903) has been shown to increase NGF synthesis [67]. NGF is known to be depleted in experimental diabetes [68] and in a study of patients with diabetic neuropathy a significant correlation was demonstrated between skin keratinocyte NGF immunostaining and skin axon-reflex vasodilation, mediated by small sensory fibers [69]. Stimulation of neurotrophin production by $1,25(\mathrm{OH})_{2} \mathrm{D}_{3}$ is correlated with a neuroprotective effect $[66,70]$ and other than NGF, glial cell line-derived neurotrophic factor $(\mathrm{GDNF})$ is also upregulated by $1,25(\mathrm{OH})_{2} \mathrm{D}_{3}$ [71]. It is notable that in central nervous system tumors, $1,25(\mathrm{OH})_{2} \mathrm{D}_{3}$ and several synthetic analogues are effective in inducing a cell death pathway in glioma cells [72-74]. Also $1,25-(\mathrm{OH}) \mathrm{D}_{3}$ regulates low affinity neurotrophin receptors (p75) [75]. Importantly, topical application of NGF in diabetic foot ulcers has resulted in promotion of healing [76]. NGF has previously been successfully studied in phase 2 clinical trials [77] but showed a lack of efficacy in a phase 3 study for DPN [78].

The prevalence of DPN can be as high as $50 \%$ [79] and symptomatic diabetic neuropathy can affect approximately 30\% of diabetic patients with neuropathy [80]. Currently there are no licensed therapies which may alter the natural history of DPN; therefore, symptom control remains the mainstay of DPN management. Even for symptom relief, effective treatment continues to remain a major challenge and 
anticonvulsants and antidepressants are first-line therapy with a 50\% reduction in pain considered a good outcome [81].

In the largest observational study to date of diabetic patients in a primary care cohort in the UK $(n=15,692)$, the prevalence of painful symptoms and painful DPN was $34 \%$ and $21 \%$ in South Asians and Europeans, respectively [82]. Additionally the adjusted risk of painful neuropathic symptoms in type 2 diabetes was double that of type 1 diabetes (OR, 2.1; 95\% CI, 1.7-2.4; $P<0.001)$ and women had a $50 \%$ increased adjusted risk of painful symptoms compared with men (OR, 1.5; 95\% CI, 1.4-1.6; $P<0.0001)$. Furthermore, despite a lower prevalence of neuropathy in South Asians (14\%) compared to Europeans (22\%) and African Caribbeans (21\%; $P<0.0001)$, painful symptoms were greatest in South Asians (38\% vs. $34 \%$ vs. $32 \%, P<0.0001)$. South Asians without neuropathy maintained a 50\% increased risk of painful neuropathic symptoms compared with other ethnic groups $(P<0.0001)$. These differences may partly be explained in relation to vitamin D deficiency as these groups have been shown to have excess vitamin D deficiency [83]. Other studies have assessed ethnic differences in DPN in a US population with variations noted in risk for DPN and diabetic autonomic neuropathy [84]. However, in an Australian study there were no significant differences between ethnic groups [85] although the ethnic mix of the last two studies differs from that in the UK.

An increasing body of data suggests that vitamin D may have not only analgesic properties but also additional neuroprotective benefits. Vitamin D deficiency and insufficiency are associated with various pain syndromes and low levels of vitamin D correlated with the presence of peripheral neuropathy in primary Sjögren's syndrome which can lead to a small fiber neuropathy [86]. Vitamin D supplementation has been shown to improve musculoskeletal pain and non-traumatic back pain in some studies [87]. However, there is a prominent contrast in treatment effects between randomized, double-blind trials that minimized bias and those with designs known to be subject to bias [87] with better treatment effects noted in the latter. Therefore, the overall evidence for the use of vitamin D for chronic pain in adults is poor because of low-quality and insufficient RCTs [87]. Pain thresholds of multiple etiologies have been reported to be lowered with vitamin D deficiency and elevated when the vitamin D deficiency is corrected [88]. Previous observational studies have demonstrated a significant link between vitamin D deficiency and DPN [89-91]. In the National Health and Nutrition Examination Survey (NHANES) 2001-2004, an unweighted sample of 591 subjects with diabetes demonstrated a significant association between vitamin D deficiency and both paresthesia (OR, 2.12; 95\% CI, 1.17-3.85) and numbness (OR, 2.04; 95\% CI, 1.18-3.52) after adjusting for obesity, co-morbidities, use of medications for neuropathy, diabetes duration, and glycemic control [89]. Furthermore, in a prospective observational study conducted by Skalli et al. [91] in 111 consecutive ambulatory patients with type 2 diabetes an association between vitamin $\mathrm{D}$ deficiency and peripheral diabetic neuropathy was found [91]. Although both subjects with and without DPN were deficient, those with DPN had approximately $4 \mathrm{ng} / \mathrm{mL}$ lower 25(OH)D levels. In a further cross-sectional study by Shehab et al. [90], vitamin $\mathrm{D}$ deficiency was an independent risk factor for DPN assessed using the neuropathy symptom score and other clinical and electrophysiological measures of DPN. The duration of diabetes was higher in the group 
with peripheral neuropathy as was elevated low-density lipoprotein-cholesterol (LDL). This latter observation may be of relevance as both vitamin $\mathrm{D}$ and cholesterol share a common metabolic pathway through 7-dehydrocholestrol [3]. In a more recent study conducted in a small homogenous population in rural Turkey, reduced serum 25(OH)D was associated with DPN [92]; interestingly, neither VDR nor VDR-binding protein differed between those with and without DPN [92]. Large nerve fiber deficits have also been associated with vitamin D status in diabetes mellitus [93]. In an age, sex, body mass index (BMI), height, and disease duration matched cohort $(n=33)$ of patients with diabetes, 25(OH)D was significantly lower in the DPN group $(21.2 \pm 11.5$ vs. $13.5 \pm 5.1 \mathrm{ng} /$ $\mathrm{mL}, P=0.001$ ) [93]. After further adjustment for all studied variables, serum vitamin $D$ had an independent and inverse association with both DPN presence and severity, as each $1 \mathrm{ng} / \mathrm{mL}$ increase in serum $25(\mathrm{OH}) \mathrm{D}$ was correlated with $2.2 \%$ and $3.4 \%$ decrease in the presence and severity of nerve conduction studies (NCV) impairment, respectively [93]. In a meta-analysis of six studies that involved a total of 1484 patients with type 2 diabetes, vitamin $\mathrm{D}$ deficiency $(<20 \mathrm{ng} / \mathrm{mL})$ was significantly associated with an increased risk of DPN [94]. The OR was 2.88 (95\% CI, 1.84-4.50; $P<0.00001)$ with an adjusted OR of 2.68 (95\% CI, 1.67-4.30; $P<0.0001)$ in a subanalysis of three studies [94], suggesting that "vitamin D deficiency is very likely to be associated with DPN in type 2 diabetic patients" [94]. Of course, hypertension itself is an independent risk factor for DPN $[95,96]$ and the interaction between vitamin $\mathrm{D}$ and the RAAS may provide a further link.

To date clinical trials of vitamin D intervention for DPN are limited. A single case report has shown reversal of symptoms in severe intractable painful diabetic neuropathy with the administration of 50,000 IU ergocalciferol (vitamin $\mathrm{D}_{2}$ ) weekly with almost complete resolution by 4 weeks [97]. Despite the fact that the patient was not severely deficient with a baseline 25(OH)D of approximately $16 \mathrm{ng} / \mathrm{mL}$, the subsequent pain relief from the weekly ergocalciferol dose enabled the discontinuation of oxycodone [97]. Lee et al. [98] conducted an open-label uncontrolled study in patients with vitamin D deficiency and 51 patients with painful DPN. After treatment with oral cholecalciferol (vitamin $\mathrm{D}_{3}$ ) at a mean dose of $2059 \mathrm{IU}$ daily for 3 months there was an improvement of approximately $50 \%$ on the Visual Analogue Scale (pain) [98]. Although the placebo effect can be considerable in trials of therapeutic agents in painful DPN, the maximal placebo effect expected would be no more than approximately 30\% [99]. Indeed a 50\% pain reduction is considered to be efficacious when evaluating interventions in painful DPN [99]. Valensi et al. [100] conducted a double-blind RCT of a compound (QR-333) containing a vitamin $\mathrm{D}$ analogue and showed positive effects on numbness, jolting pain, and irritation in subjects with painful DPN. However, the outcomes of this study are somewhat confounded as QR-333 contained quercetin, a flavonoid with aldose reductase inhibitor effects, which is one of the key pathogenetic pathways causing diabetic neuropathy.

One of the key 'hard endpoints' of DPN is foot ulceration, which may eventually lead to lower limb amputation and significant morbidity and mortality [101]. In a cross-sectional study of diabetic patients without $(n=162)$ and with $(n=162)$ plantar ulcers, lower $25(\mathrm{OH}) \mathrm{D}$ status was associated with plantar ulceration in patients with 
diabetes (6.3 vs. $28 \mathrm{ng} / \mathrm{mL}, P<0.005$ ) [102]. In a further study by Tiwari et al. [103], vitamin D deficiency was more prevalent and severe in patients with diabetic foot infection. Cases of foot infection $(n=125)$ had a greater risk of vitamin D deficiency $(25(\mathrm{OH}) \mathrm{D}<20 \mathrm{ng} / \mathrm{mL})$ than controls $(n=164)$ with an OR of 1.8 (95\% CI, 1.1-3.0; $P=0.02$ ) and the risk of severe vitamin $\mathrm{D}$ deficiency $(25(\mathrm{OH}) \mathrm{D}<10 \mathrm{ng} /$ $\mathrm{mL}$ ) was significantly higher in cases than in controls with an OR of 4.0 (95\% CI, 2.4-6.9; $P<0.0001)$ [103].

\section{VITAMIN D AND DIABETIC NEPHROPATHY}

Considerable data exist on the role of vitamin D in diabetic nephropathy [104]. Patients with chronic kidney disease (CKD) are known to have deficiency of both 25(OH)D and $1,25(\mathrm{OH})_{2} \mathrm{D}$, which is associated with a high cardiovascular mortality. These risks can be partially ameliorated by treatment with vitamin D analogues [105]. Although in patients with CKD, higher levels of vitamin $\mathrm{D}$ may also be associated with vascular calcification [106]. Experimental studies have shown a role of the VDR, and VDR-mediated vitamin D actions are thought to be renoprotective in diabetic nephropathy [107]. In an experimental study, vitamin D/VDR signaling in podocytes played a critical role in the protection of the kidney from diabetic injury [108]. Analysis of the NHAHES (2001-2006) cross-sectional data showed that there was an independent association between vitamin D deficiency and insufficiency with the presence of nephropathy [109]. In a small double-blind, randomized placebo-controlled, crossover trial of paracalcitriol (a vitamin D analogue) in patients with proteinuria despite adequate RAAS blockade, the urinary albumin excretion rate was significantly further lowered compared to placebo [110]. Furthermore, combination therapy with an AT1 blocker and a vitamin D analogue markedly ameliorated diabetic nephropathy in an experimental model of diabetic nephropathy [111]. In the VITAL study (ClinicalTrials.gov identifier, NCT00421733), a placebo-controlled, double-blind RCT, paracalcitriol (a vitamin D analogue) added to RAAS inhibition at a dose of $2 \mu \mathrm{g}$ /day significantly lowered blood pressure and residual albuminuria in patients with diabetic nephropathy [112], further highlighting the role of vitamin $\mathrm{D}$ as a potent RAAS inhibitor $[113,114]$. Recently, a systematic review and meta-analysis by Derakhshanian et al. [115] suggested that despite a higher risk for nephropathy in vitamin D-deficient patients with diabetes, vitamin $\mathrm{D}$ supplementation did not support causality in this association. A pooled data of urinary albumin-creatinine ratio levels in clinical trials (five trials, $n=219$ ) suggested no significant change following vitamin D supplementation [115]. However, these studies were small and heterogeneous and the vitamin D replacement dose was small. Thus, larger well-designed RCTs with adequate vitamin $\mathrm{D}$ supplementation in diabetic nephropathy are required.

\section{VITAMIN D AND DIABETIC RETINOPATHY}

25(OH)D concentrations are associated with optic chiasm volume [116] and several studies have found an association between vitamin $\mathrm{D}$ deficiency and age-related macular degeneration (AMD) $[117,118]$. In a mouse model of ischemic retinopathy, $1,25(\mathrm{OH})_{2} \mathrm{D}$ was shown to inhibit neovascularization in retinal tissue [119]. In a Turkish cohort of 66 subjects, 
Aksoy et al. [120] demonstrated an inverse correlation between worsening diabetic retinopathy and lower 1,25-dihydroxyvitamin $\mathrm{D}_{3}$ (active vitamin D). In 50 diabetic patients with early-stage diabetic retinopathy (DR) with vitamin $\mathrm{D}$ deficiency and 50 early-stage DR without vitamin D deficiency, vitamin D deficiency was associated with early retinal nerve fibre layer (RNFL) thinning [121]. Furthermore, in a Korean study sampling 18,363 from the NHANES (2008-2012), $25(\mathrm{OH}) \mathrm{D}$ was associated with diabetic retinopathy [122]. Similar results have been replicated in a Chinese population with type 2 diabetes [123] and a Japanese population with type 1 diabetes [124]. However, in the third NHANES, no relationship was found between 25(OH)D levels and retinopathy severity [125]. Also the EURODIAB prospective complications study showed no significant relationship between 25(OH)D and retinopathy, despite a positive relationship with microalbuminuria [126]. Indeed, most recently, Alam et al. [127] have shown no association between serum $25(\mathrm{OH}) \mathrm{D}$ concentrations and the presence and severity of diabetic retinopathy or maculopathy; however, the marked deficiency in their population may have confounded the study as approximately $91 \%$ of subjects were deficient/insufficient $\quad(25(\mathrm{OH}) \mathrm{D} \quad<30 \mathrm{ng} / \mathrm{mL})$ [127]. Thus further studies are required to elucidate the relationship between vitamin D and DR.

\section{CONCLUSIONS}

The prevalence of vitamin D deficiency is in pandemic proportions in the UK and worldwide, particularly in the diabetic population. An increasing body of literature suggests a possible pathogenetic role of vitamin $\mathrm{D}$ in the long-term complications of diabetes and vitamin D deficiency may also exacerbate symptoms of painful DPN. Despite a number of well-designed observational studies a causal link remains to be demonstrated. The association between vitamin $\mathrm{D}$ status and cardiometabolic outcomes is uncertain, especially as intervention trials have shown no clinically significant effect of vitamin D supplementation. However, short-term underpowered interventions with low doses of vitamin D may have produced limited benefits. Given the widespread propensity to deficiency and its low side effect profile, vitamin $\mathrm{D}$ therapy represents a promising therapeutic intervention in the treatment of diabetic complications. In particular, there is a significant need for good quality RCTs using therapeutic doses (approximately 4000 IU/day) of vitamin D in painful DPN.

\section{ACKNOWLEDGMENTS}

No funding or sponsorship was received for publication of this article. All named authors meet the International Committee of Medical Journal Editors (ICMJE) criteria for authorship of this manuscript, take responsibility for the integrity of the work as a whole, and have given final approval for the version to be published.

Disclosures. Uazman Alam, Vilashini Arul-Devah, Saad Javed, and Rayaz A. Malik have nothing to disclose with regards to the publication of this article. 
Compliance with Ethics Guidelines. This review is based on previously conducted studies and does not involve any new studies of human or animal subjects performed by any of the authors.

Open Access. This article is distributed under the terms of the Creative Commons AttributionNonCommercial 4.0 International License (http://creativecommons.org/licenses/by-nc/4. $0 /$ ), which permits any noncommercial use, distribution, and reproduction in any medium, provided you give appropriate credit to the original author(s) and the source, provide a link to the Creative Commons license, and indicate if changes were made.

\section{REFERENCES}

1. Holick MF. Vitamin D deficiency. N Engl J Med. 2007;357:266-81.

2. Alam U, Najam O, Al-Himdani S, et al. Marked vitamin $\mathrm{D}$ deficiency in patients with diabetes in the UK: ethnic and seasonal differences and an association with dyslipidaemia. Diabet Med. 2012;29:1343-5.

3. Holick MF. Vitamin D deficiency. N Engl J Med. 2007;357:266-81.

4. MacLaughlin J, Holick MF. Aging decreases the capacity of human skin to produce vitamin D3. J Clin Investig. 1985;76:1536-8.

5. Lips P. Vitamin D physiology. Prog Biophys Mol Biol. 2006;92:4-8.

6. Ross AC, Manson JE, Abrams SA, et al. The 2011 report on dietary reference intakes for calcium and vitamin $\mathrm{D}$ from the Institute of Medicine: what clinicians need to know. J Clin Endocrinol Metab. 2011;96:53-8.

7. Rosen CJ, Abrams SA, Aloia JF, et al. IOM committee members respond to Endocrine Society vitamin D guideline. J Clin Endocrinol Metab. 2012;97:1146-52.
8. Heaney RP, Holick MF. Why the IOM recommendations for vitamin $\mathrm{D}$ are deficient. J Bone Miner Res. 2011;26:455-7.

9. Spiro A, Buttriss JL. Vitamin D: an overview of vitamin D status and intake in Europe. Nutr Bull. 2014;39:322-50.

10. Bouillon R, Van Schoor NM, Gielen E, et al. Optimal vitamin D status: a critical analysis on the basis of evidence-based medicine. J Clin Endocrinol Metab. 2013;98:E1283-304.

11. Temmerman JC. Vitamin D and cardiovascular disease. J Am Coll Nutr. 2011;30:167-70.

12. Haussler MR, Jurutka PW, Mizwicki M, Norman AW. Vitamin D receptor (VDR)-mediated actions of 1alpha, $25(\mathrm{OH})(2)$ vitamin $\mathrm{D}(3)$ : genomic and non-genomic mechanisms. Best Pract Res Clin Endocrinol Metab. 2011;25:543-59.

13. Haussler MR, Whitfield GK, Kaneko I, et al. Molecular mechanisms of vitamin D action. Calcif Tissue Int. 2013;92:77-98.

14. Johnson JA, Grande JP, Windebank AJ, Kumar R. 1,25-Dihydroxyvitamin $\mathrm{D}(3)$ receptors in developing dorsal root ganglia of fetal rats. Brain Res Dev Brain Res. 1996;92:120-4.

15. Wang TJ, Pencina MJ, Booth SL, et al. Vitamin D deficiency and risk of cardiovascular disease. Circulation. 2008;117:503-11.

16. Giovannucci E, Liu Y, Hollis BW, Rimm EB. 25-Hydroxyvitamin D and risk of myocardial infarction in men: a prospective study. Arch Intern Med. 2008;168:1174-80.

17. Dobnig H, Pilz S, Scharnagl H, et al. Independent association of low serum 25-hydroxyvitamin D and 1,25-dihydroxyvitamin D levels with all-cause and cardiovascular mortality. Arch Intern Med. 2008;168:1340-9.

18. Kienreich $\mathrm{K}$, Tomaschitz A, Verheyen $\mathrm{N}$, et al. Vitamin D and cardiovascular disease. Nutrients. 2013;5:3005-21.

19. Molinari C, Uberti F, Grossini E, et al. $1 \alpha, 25$-Dihydroxycholecalciferol induces nitric oxide production in cultured endothelial cells. Cell Physiol Biochem. 2011;27:661-8.

20. Oh J, Weng S, Felton SK, et al. 1,25(OH)2 vitamin D inhibits foam cell formation and suppresses macrophage cholesterol uptake in patients with type 2 diabetes mellitus. Circulation. 2009;120:687-98. 
21. Tare M, Emmett SJ, Coleman HA, et al. Vitamin D insufficiency is associated with impaired vascular endothelial and smooth muscle function and hypertension in young rats. J Physiol. 2011;589:4777-86.

22. Swapna N, Vamsi UM, Usha G, Padma T. Risk conferred by FokI polymorphism of vitamin D receptor (VDR) gene for essential hypertension. Indian J Hum Genet. 2011;17:201-6.

23. Brondum-Jacobsen $\mathrm{P}$, Nordestgaard BG, Schnohr $\mathrm{P}$, Benn M. 25-Hydroxyvitamin $\mathrm{D}$ and symptomatic ischemic stroke: an original study and meta-analysis. Ann Neurol. 2013;73:38-47.

24. Kojima G, Bell C, Abbott RD, et al. Low dietary vitamin $D$ predicts 34-year incident stroke: the Honolulu Heart Program. Stroke. 2012;43:2163-7.

25. Chaudhuri JR, Mridula KR, Alladi S, et al. Serum 25-hydroxyvitamin D deficiency in ischemic stroke and subtypes in Indian patients. J Stroke. 2014;16:44-50.

26. Judd SE, Tangpricha V. Vitamin D deficiency and risk for cardiovascular disease. Am J Med Sci. 2009;338:40-4.

27. Li YC, Qiao G, Uskokovic M, Xiang W, Zheng W, Kong J. Vitamin D: a negative endocrine regulator of the renin-angiotensin system and blood pressure. J Steroid Biochem Mol Biol. 2004;89-90:387-92.

28. Carbone F, Mach F, Vuilleumier N, Montecucco F. Potential pathophysiological role for the vitamin $\mathrm{D}$ deficiency in essential hypertension. World J Cardiol. 2014;6:260-76.

29. Reja A, Tesfaye S, Harris ND, Ward JD. Is ACE inhibition with lisinopril helpful in diabetic neuropathy? Diabet Med. 1995;12:307-9.

30. Malik RA, Williamson S, Abbott C, et al. Effect of angiotensin-converting-enzyme (ACE) inhibitor trandolapril on human diabetic neuropathy: randomised double-blind controlled trial. Lancet. 1998;352:1978-81.

31. Ustundag B, Cay M, Naziroglu M, Dilsiz N, Crabbe MJ, Ilhan N. The study of renin-angiotensin-aldosterone in experimental diabetes mellitus. Cell Biochem Funct. 1999;17:193-8.

32. Trivedi DP, Doll R, Khaw KT. Effect of four monthly oral vitamin D3 (cholecalciferol) supplementation on fractures and mortality in men and women living in the community: randomised double blind controlled trial. BMJ. 2003;326:469.
33. Prince RL, Austin N, Devine A, Dick IM, Bruce D, Zhu K. Effects of ergocalciferol added to calcium on the risk of falls in elderly high-risk women. Arch Intern Med. 2008;168:103-8.

34. Wang L, Manson JE, Song Y, Sesso HD. Systematic review: vitamin $\mathrm{D}$ and calcium supplementation in prevention of cardiovascular events. Ann Intern Med. 2010;152:315-23.

35. Hsia J, Heiss G, Ren H, et al. Calcium/vitamin D supplementation and cardiovascular events. Circulation. 2007;115:846-54.

36. de Boer IH, Tinker LF, Connelly S, et al. Calcium plus vitamin D supplementation and the risk of incident diabetes in the Women's Health Initiative. Diabetes Care. 2008;31:701-7.

37. Mathieu C, Gysemans C, Giulietti A, Bouillon R. Vitamin $\mathrm{D}$ and diabetes. Diabetologia. 2005;48:1247-57.

38. Lee JH, O'Keefe JH, Bell D, Hensrud DD, Holick MF. Vitamin D deficiency an important, common, and easily treatable cardiovascular risk factor? J Am Coll Cardiol. 2008;52:1949-56.

39. Scragg R, Sowers M, Bell C. Serum 25-hydroxyvitamin $\mathrm{D}$, diabetes, and ethnicity in the Third National Health and Nutrition Examination Survey. Diabetes Care. 2004;27:2813-8.

40. Mitri J, Dawson-Hughes B, Hu FB, Pittas AG. Effects of vitamin $\mathrm{D}$ and calcium supplementation on pancreatic beta cell function, insulin sensitivity, and glycemia in adults at high risk of diabetes: the Calcium and Vitamin D for Diabetes Mellitus (CaDDM) randomized controlled trial. Am J Clin Nutr. 2011;94:486-94.

41. Hutchinson MS, Figenschau Y, Njolstad I, Schirmer H, Jorde R. Serum 25-hydroxyvitamin D levels are inversely associated with glycated haemoglobin $(\mathrm{HbA}(1 \mathrm{c}))$. The Tromso Study. Scand J Clin Lab Invest. 2011;71:399-406.

42. Zoppini G, Galletti A, Targher G, et al. Glycated haemoglobin is inversely related to serum vitamin D levels in type 2 diabetic patients. PLoS One. 2013;8:e82733.

43. Devaraj S, Jialal G, Cook T, Siegel D, Jialal I. Low vitamin $D$ levels in Northern American adults with the metabolic syndrome. Horm Metab Res. 2011;43:72-4.

44. Hypponen E, Laara E, Reunanen A, Jarvelin MR, Virtanen SM. Intake of vitamin D and risk of type 1 diabetes: a birth-cohort study. Lancet. 2001;358:1500-3. 
45. von Hurst PR, Stonehouse W, Coad J. Vitamin D supplementation reduces insulin resistance in South Asian women living in New Zealand who are insulin resistant and vitamin $\mathrm{D}$ deficient-a randomised, placebo-controlled trial. Br J Nutr. 2010;103:549-55.

46. Herrmann M, Sullivan DR, Veillard AS, et al. Serum 25-hydroxyvitamin D: a predictor of macrovascular and microvascular complications in patients with type 2 diabetes. Diabetes Care. 2015;38:521-8.

47. Joergensen C, Hovind P, Schmedes A, Parving H-H, Rossing P. Vitamin D levels, microvascular complications, and mortality in type 1 diabetes. Diabetes Care. 2011;34:1081-5.

48. Holmøy T, Moen SM. Assessing vitamin D in the central nervous system. Acta Neurol Scand Suppl. 2010;122:88-92.

49. Alam U, Asghar O, Malik RA. Are vitamin D and B deficiency relevant to the pathogenesis and treatment of diabetic neuropathy? Future Neurol. 2012;7:235-8.

50. Simon KC, Munger KL, Ascherio A. Vitamin D and multiple sclerosis: epidemiology, immunology, and genetics. Curr Opin Neurol. 2012;25:246-51.

51. Simon KC, Munger KL, Xing Y, Ascherio A. Polymorphisms in vitamin D metabolism related genes and risk of multiple sclerosis. Mult Scler. 2010;16:133-8.

52. van der Mei IA, Ponsonby AL, Dwyer T, et al. Vitamin D levels in people with multiple sclerosis and community controls in Tasmania, Australia. J Neurol. 2007;254:581-90.

53. Simpson S Jr, Taylor B, Blizzard L, et al. Higher 25-hydroxyvitamin D is associated with lower relapse risk in multiple sclerosis. Ann Neurol. 2010;68:193-203.

54. Soilu-Hanninen M, Laaksonen M, Laitinen I, Eralinna JP, Lilius EM, Mononen I. A longitudinal study of serum 25-hydroxyvitamin $\mathrm{D}$ and intact parathyroid hormone levels indicate the importance of vitamin $\mathrm{D}$ and calcium homeostasis regulation in multiple sclerosis. J Neurol Neurosurg Psychiatry. 2008;79:152-7.

55. Knekt P, Kilkkinen A, Rissanen H, Marniemi J, Saaksjarvi K, Heliovaara M. Serum vitamin D and the risk of Parkinson disease. Arch Neurol. 2010;67:808-11.

56. Llewellyn DJ, Lang IA, Langa KM, et al. Vitamin D and risk of cognitive decline in elderly persons. Arch Intern Med. 2010;170:1135-41.
57. Burton JM, Kimball S, Vieth R, et al. A phase I/II dose-escalation trial of vitamin D3 and calcium in multiple sclerosis. Neurology. 2010;74:1852-9.

58. Pozuelo-Moyano B, Benito-Leon J, Mitchell AJ, Hernandez-Gallego J. A systematic review of randomized, double-blind, placebo-controlled trials examining the clinical efficacy of vitamin D in multiple sclerosis. Neuroepidemiology. 2013;40:147-53.

59. Aloe L, Rocco ML, Bianchi P, Manni L. Nerve growth factor: from the early discoveries to the potential clinical use. J Transl Med. 2012;10:239.

60. Garcion E, Wion-Barbot N, Montero-Menei CN, Berger F, Wion D. New clues about vitamin D functions in the nervous system. Trends Endocrinol Metab. 2002;13:100-5.

61. Fex Svennigsen A, Dahlin LB. Repair of the peripheral nerve-remyelination that works. Brain Sci. 2013;3:1182-97.

62. Ito S, Ohtsuki S, Nezu Y, Koitabashi Y, Murata S, Terasaki T. 1 $\alpha, 25$-Dihydroxyvitamin D3 enhances cerebral clearance of human amyloid- $\beta$ peptide $(1-40)$ from mouse brain across the blood-brain barrier. Fluids Barriers CNS. 2011;8:1-10.

63. Neveu I, Naveilhan $P$, Jehan $F$, et al. 1,25-Dihydroxyvitamin D3 regulates the synthesis of nerve growth factor in primary cultures of glial cells. Brain Res Mol Brain Res. 1994;24:70-6.

64. Musiol IM, Feldman D. 1,25-Dihydroxyvitamin D3 induction of nerve growth factor in L929 mouse fibroblasts: effect of vitamin D receptor regulation and potency of vitamin D3 analogs. Endocrinology. 1997;138:12-8.

65. Brown J, Bianco JI, McGrath JJ, Eyles DW. 1,25-Dihydroxyvitamin D3 induces nerve growth factor, promotes neurite outgrowth and inhibits mitosis in embryonic rat hippocampal neurons. Neurosci Lett. 2003;343:139-43.

66. Riaz S, Malcangio M, Miller M, Tomlinson DR. A vitamin $\mathrm{D}(3)$ derivative (CB1093) induces nerve growth factor and prevents neurotrophic deficits in streptozotocin-diabetic rats. Diabetologia. 1999;42:1308-13.

67. Jehan F, Neveu I, Barbot N, Binderup L, Brachet P, Wion D. MC903, an analogue of 1,25-dihydroxyvitamin D3, increases the synthesis of nerve growth factor. Eur J Pharmacol. 1991;208:189-91.

68. Hellweg R, Wohrle M, Hartung HD, Stracke H, Hock C, Federlin K. Diabetes mellitus-associated 
decrease in nerve growth factor levels is reversed by allogeneic pancreatic islet transplantation. Neurosci Lett. 1991;125:1-4.

69. Anand P, Terenghi G, Warner G, Kopelman P, Williams-Chestnut RE, Sinicropi DV. The role of endogenous nerve growth factor in human diabetic neuropathy. Nat Med. 1996;2:703-7.

70. Wang Y, Chiang YH, Su TP, et al. Vitamin D(3) attenuates cortical infarction induced by middle cerebral arterial ligation in rats. Neuropharmacology. 2000;39:873-80.

71. Naveilhan P, Neveu I, Wion D, Brachet P. 1,25-Dihydroxyvitamin D3, an inducer of glial cell line-derived neurotrophic factor. NeuroReport. 1996;7:2171-5.

72. Naveilhan P, Berger F, Haddad K, et al. Induction of glioma cell death by $1,25(\mathrm{OH}) 2$ vitamin D3: towards an endocrine therapy of brain tumors? J Neurosci Res. 1994;37:271-7.

73. Baudet C, Chevalier G, Naveilhan P, Binderup L, Brachet $P$, Wion D. Cytotoxic effects of 1 alpha,25-dihydroxyvitamin D3 and synthetic vitamin D3 analogues on a glioma cell line. Cancer Lett. 1996;100:3-10.

74. Baudet C, Chevalier G, Chassevent A, et al. 1,25-Dihydroxyvitamin D3 induces programmed cell death in a rat glioma cell line. J Neurosci Res. 1996;46:540-50.

75. Naveilhan P, Neveu I, Baudet C, et al. 1,25-Dihydroxyvitamin D3 regulates the expression of the low-affinity neurotrophin receptor. Brain Res Mol Brain Res. 1996;41:259-68.

76. Generini S, Tuveri MA, Matucci Cerinic M, Mastinu F, Manni L, Aloe L. Topical application of nerve growth factor in human diabetic foot ulcers. A study of three cases. Exp Clin Endocrinol Diabetes. 2004;112:542-4.

77. Apfel SC, Kessler JA, Adornato BT, Litchy WJ, Sanders C, Rask CA. Recombinant human nerve growth factor in the treatment of diabetic polyneuropathy. NGF Study Group. Neurology. 1998;51:695-702.

78. Apfel SC, Schwartz S, Adornato BT, et al. Efficacy and safety of recombinant human nerve growth factor in patients with diabetic polyneuropathy: a randomized controlled trial. rhNGF Clinical Investigator Group. JAMA. 2000;284:2215-21.

79. Shaw J, Zimmet P. The epidemiology of diabetic neuropathy. Diabetes Revs. 1999;7:245-52.
80. Skljarevski V, Malik RA. Clinical diagnosis of diabetic neuropathy. In: Veves AMR, editor. Diabetic neuropathy: clinical management. 2nd ed. New Jersey: Humana; 2007.

81. Tavakoli M, Asghar O, Alam U, Petropoulos IN, Fadavi H, Malik RA. Review: novel insights on diagnosis, cause and treatment of diabetic neuropathy: focus on painful diabetic neuropathy. Ther Adv Endocrinol Metab. 2010;1:69-88.

82. Abbott CA, Malik RA, van Ross ER, Kulkarni J, Boulton AJ. Prevalence and characteristics of painful diabetic neuropathy in a large community-based diabetic population in the UK. Diabetes Care. 2011;34:2220-4.

83. Tahrani AA, Ball A, Shepherd L, Rahim A, Jones AF, Bates A. The prevalence of vitamin D abnormalities in South Asians with type 2 diabetes mellitus in the UK. Int J Clin Pract. 64:351-5.

84. Cohen JA, Jeffers BW, Faldut D, Marcoux M, Schrier RW. Risks for sensorimotor peripheral neuropathy and autonomic neuropathy in non-insulin-dependent diabetes mellitus (NIDDM). Muscle Nerve. 1998;21:72-80.

85. Sorensen L, Molyneaux L, Yue DK. Insensate versus painful diabetic neuropathy: the effects of height, gender, ethnicity and glycaemic control. Diabetes Res Clin Pract. 2002;57:45-51.

86. Agmon-Levin N, Kivity S, Tzioufas AG, et al. Low levels of vitamin-D are associated with neuropathy and lymphoma among patients with Sjogren's syndrome. J Autoimmun. 2012;39:234-9.

87. Straube S, Andrew Moore R, Derry S, McQuay HJ. Vitamin D and chronic pain. Pain. 2009;141:10-3.

88. Plotnikoff GA, Quigley JM. Prevalence of severe hypovitaminosis $\mathrm{D}$ in patients with persistent, nonspecific musculoskeletal pain. Mayo Clinic Proc. 2003;78:1463-70.

89. Soderstrom LH, Johnson SP, Diaz VA, Mainous AG 3rd. Association between vitamin D and diabetic neuropathy in a nationally representative sample: results from 2001-2004 NHANES. Diabet Med. 2012;29:50-5.

90. Shehab D, Al-Jarallah K, Mojiminiyi OA, Al Mohamedy H, Abdella NA. Does vitamin D deficiency play a role in peripheral neuropathy in type 2 diabetes? Diabet Med. 2012;29:43-9.

91. Skalli S, Muller M, Pradines S, Halimi S, Wion-Barbot N. Vitamin D deficiency and peripheral diabetic neuropathy. Eur J Intern Med. 2012;23:e67-8. 
92. Celikbilek A, Gocmen AY, Tanik N, et al. Decreased serum vitamin D levels are associated with diabetic peripheral neuropathy in a rural area of Turkey. Acta Neurol Belg. $2015 ; 115: 47-52$.

93. Alamdari A, Mozafari R, Tafakhori A, et al, Esteghamati A. An inverse association between serum vitamin D levels with the presence and severity of impaired nerve conduction velocity and large fiber peripheral neuropathy in diabetic subjects. Neurol Sci. 2015;36(7):1121-6.

94. Lv WS, Zhao WJ, Gong SL, et al. Serum 25-hydroxyvitamin D levels and peripheral neuropathy in patients with type 2 diabetes: a systematic review and meta-analysis. J Endocrinol Invest. 2015;38:513-8.

95. Tesfaye S, Selvarajah D. The Eurodiab study: what has this taught us about diabetic peripheral neuropathy? Curr Diab Rep. 2009;9:432-4.

96. Tesfaye S, Chaturvedi N, Eaton SEM, et al. Vascular risk factors and diabetic neuropathy. $\mathrm{N}$ Engl J Med. 2005;352:341-50.

97. Bell DSH. Reversal of the symptoms of diabetic neuropathy through correction of vitamin D deficiency in a type 1 diabetic patient. Case Rep Endocrinol. 2012;2012:3.

98. Lee P, Chen R. Vitamin D as an analgesic for patients with type 2 diabetes and neuropathic pain. Arch Intern Med. 2008;168:771-2.

99. Tavakoli M, Asghar O, Alam U, Petropoulos IN, Fadavi H, Malik RA. Novel insights on diagnosis, cause and treatment of diabetic neuropathy: focus on painful diabetic neuropathy. Ther Adv Endocrinol Metab. 2010;1:69-88.

100. Valensi P, Le Devehat C, Richard JL, et al. A multicenter, double-blind, safety study of QR-333 for the treatment of symptomatic diabetic peripheral neuropathy. A preliminary report. J Diabetes Complications. 2005;19:247-53.

101. Boulton AJ, Vileikyte L, Ragnarson-Tennvall G, Apelqvist J. The global burden of diabetic foot disease. Lancet. 2005;366:1719-24.

102. Zubair M, Malik A, Meerza D, Ahmad J. 25-Hydroxyvitamin D [25(OH)D] levels and diabetic foot ulcer: is there any relationship? Diabetes Metab Syndr. 2013;7:148-53.

103. Tiwari S, Pratyush DD, Gupta B, et al. Prevalence and severity of vitamin $\mathrm{D}$ deficiency in patients with diabetic foot infection. $\mathrm{Br} \mathrm{J}$ Nutr. 2013;109:99-102.
104. Agarwal R. Vitamin D, proteinuria, diabetic nephropathy, and progression of CKD. Cli J Am Soc Nephrol. 2009;4:1523-8.

105. Teng M, Wolf M, Lowrie E, Ofsthun N, Lazarus JM, Thadhani R. Survival of patients undergoing hemodialysis with paricalcitol or calcitriol therapy. N Engl J Med. 2003;349:446-56.

106. Zittermann A, Schleithoff SS, Koerfer R. Vitamin D and vascular calcification. Curr Opin Lipidol. 2007; 18:41-6.

107. Zhang Z, Sun L, Wang Y, et al. Renoprotective role of the vitamin $D$ receptor in diabetic nephropathy. Kidney Int. 2007;73:163-71.

108. Wang Y, Deb DK, Zhang Z, et al. Vitamin D receptor signaling in podocytes protects against diabetic nephropathy. J Am Soc Nephrol. 2012;23:1977-86.

109. Diaz VA, Mainous AG, Carek PJ, Wessell AM, Everett CJ. The association of vitamin D deficiency and insufficiency with diabetic nephropathy: implications for health disparities. J Am Board Fam Med. 2009;22:521-7.

110. Joergensen C, Tarnow L, Goetze JP, Rossing P. Vitamin D analogue therapy, cardiovascular risk and kidney function in people with type 1 diabetes mellitus and diabetic nephropathy: a randomized trial. Diabet Med. 2015;32:374-81.

111. Zhang Z, Zhang Y, Ning G, Deb DK, Kong J, Li YC. Combination therapy with AT1 blocker and vitamin $\mathrm{D}$ analog markedly ameliorates diabetic nephropathy: blockade of compensatory renin increase. Proc Natl Acad Sci USA. 2008;105:15896-901.

112. de Zeeuw D, Agarwal R, Amdahl M, et al. Selective vitamin $\mathrm{D}$ receptor activation with paricalcitol for reduction of albuminuria in patients with type 2 diabetes (VITAL study): a randomised controlled trial. Lancet. 2010;376:1543-51.

113. Qiao G, Kong J, Uskokovic M, Li YC. Analogs of 1alpha,25-dihydroxyvitamin $\mathrm{D}(3)$ as novel inhibitors of renin biosynthesis. J Steroid Biochem Mol Biol. 2005;96:59-66.

114. Vaidya A, Williams JS. The relationship between vitamin $\mathrm{D}$ and the renin-angiotensin system in the pathophysiology of hypertension, kidney disease, and diabetes. Metabolism. 2012;61:450-8.

115. Derakhshanian H, Shab-Bidar S, Speakman JR, Nadimi H, Djafarian K. Vitamin D and diabetic nephropathy: a systematic review and meta-analysis. Nutrition. 2015;31:1189-94. 
116. Annweiler C, Beauchet O, Bartha R, Graffe A, Milea $\mathrm{D}$, Montero-Odasso M. Association between serum 25-hydroxyvitamin D concentration and optic chiasm volume. J Am Geriatr Soc. 2013;61:1026-8.

117. Golan S, Shalev V, Treister G, Chodick G, Loewenstein A. Reconsidering the connection between vitamin $\mathrm{D}$ levels and age-related macular degeneration. Eye (Lond). 2011;25:1122-9.

118. Singh A, Falk MK, Subhi Y, Sorensen TL. The association between plasma 25 -hydroxyvitamin D and subgroups in age-related macular degeneration: a cross-sectional study. PLoS One. 2013;8:e70948.

119. Albert DM, Scheef EA, Wang S, et al. Calcitriol is a potent inhibitor of retinal neovascularization. Invest Ophthalmol Vis Sci. 2007;48:2327-34.

120. Aksoy H, Akçay F, Kurtul N, Baykal O, Avci B. Serum 1,25 dihydroxy vitamin $\mathrm{D}(1,25(\mathrm{OH}) 2 \mathrm{D} 3)$, 25 hydroxy vitamin $\mathrm{D}(25(\mathrm{OH}) \mathrm{D})$ and parathormone levels in diabetic retinopathy. Clin Biochem. 2000;33:47-51.

121. Gungor A, Ates O, Bilen H, Kocer I. Retinal nerve fiber layer thickness in early-stage diabetic retinopathy with vitamin D deficiency. Invest Ophthalmol Vis Sci. 2015;56:6433-7.

122. Jee D, Han K, Kim EC. Inverse association between high blood 25-hydroxyvitamin $\mathrm{D}$ levels and diabetic retinopathy in a representative Korean population. PLoS One. 2014;9:e115199.

123. He R, Shen J, Liu F, et al. Vitamin D deficiency increases the risk of retinopathy in Chinese patients with type 2 diabetes. Diabet Med. 2014;31:1657-64.

124. Shimo N, Yasuda T, Kaneto H, et al. Vitamin D deficiency is significantly associated with retinopathy in young Japanese type 1 diabetic patients. Diabetes Res Clin Pract. 2014;106:e41-3.

125. Patrick PA, Visintainer PF, Shi Q, Weiss IA, Brand DA. Vitamin D and retinopathy in adults with diabetes mellitus. Arch Ophthalmol. 2012;130:756-60.

126. Engelen L, Schalkwijk C, Eussen SJ, et al. Low 25-hydroxyvitamin D2 and 25-hydroxyvitamin D3 levels are independently associated with macroalbuminuria, but not with retinopathy and macrovascular disease in type 1 diabetes: the EURODIAB prospective complications study. Cardiovasc Diabetol. 2015;14:67.

127. Alam $U$, Amjad $\mathrm{Y}$, Chan AW, Asghar $\mathrm{O}$, Petropoulos IN, Malik RA. Vitamin D deficiency is not associated with diabetic retinopathy or maculopathy. J Diabetes Res. 2016. 2016:6156217. 